\title{
The Prague School’s Early Concept of Distinctive Features in Multilingual Texts: A Chapter in the History of Structuralist Phonology
}

\author{
Changliang Qu
}

\begin{abstract}
In the rise and development of modern phonology, the Prague School undoubtedly played the vital role. Although Saussure suggested that "syntagmatic" is one of the two most important features of linguistic signs, Jakobson yet discovered on the phonological level the "paradigmatic" linguistic unit distinctive feature, which served as an essential concept in late $20^{\text {th }}$ century phonology. Jakobson's theory of distinctive feature is typically made known via the books he published in the United States after WWII. However, his idea of distinctive feature had already been initiated in the 1930s during the classic period of the Prague School. The term "distinctive feature" was also used directly. The term and the idea were actively responded by other members of the circle like Trubetzkoy and Vachek and came to turn mature. Published on different occasions, the texts that witnessed this historical process were written in different languages. Only when these multilingual texts are studied comprehensively can one depict a full trail of the early history of distinctive feature, the paradigmatic phonological unit. Based on the works written by Jakobson, Trubetzkoy, Vachek and other circle members during 1931 to 1939 in English, French, German and Czech, this essay intends to reveal how Prague School contributed to the idea of paradigmatic phonological unit, and how it improved the limitation of Saussure's view of linguistic symbol.
\end{abstract}

Index Terms - Distinctive feature, linguistic historiography, phonological unit, Prague linguistic circle.

\section{INTRODUCTION}

In the rise and development of modern phonology, the Prague School successfully initiated some vital terms and concepts that have been serving as the keynotes of the field. Taking the concept "distinctive feature" as an example, although Ferdinand de Saussure (1857-1913) suggested that "syntagmatic" is one of the two most important characteristics of linguistic signs, Roman Jakobson (1896-1982) yet discovered on the phonological level the "paradigmatic" linguistic unit - distinctive feature, the functional sub-phonemic unit.

While the ideas on distinctive feature is undoubtedly among Jakobson's most remarkable contributions to phonology, they are often regarded as a vital difference between the later

Manuscript received December14, 2017; revised February 20, 2018. This work is supported in part by the National Social Science Foundation of China under Grant 16BYY007.

Changliang $\mathrm{Qu}$ is with Department of English Linguistics, School of International Business, Dalian University of Foreign Languages, Dalian P.R. China (e-mail: quchangliang@dlufl.edu.cn). development of Jakobsonian phonology and the classical Praguian phonology. Anderson noted, for example, that "in the thirties, Jakobson's views on phonology were developed very much within the context of his cooperation with Trubetzkoy and the other members of the Prague School” [1], and that "it was only after Trubetzkoy's death in 1938 that Jakobson's own position began to diverge in significant ways from that underlying their earlier work" [1]. In this sense, the late $1930 \mathrm{~s}$ is naturally considered a vital pivot inside Jakobsonian phonology. In "Observations sur le classement phonologique des consonnes”, the article he wrote in French and presented to the Third International Congress of Phonetic Sciences in 1938 in Ghent, Jakobson made a most far-reaching breakthrough as he declared that "[n]ous identifions les phonèmes d'une langue donnée en les décomposant en leurs caractères phonologiques constitutifs, c'est-à-dire que nous établissons pour chaque phonème quelles qualités l'opposent aux autres phonèmes du système en question" (We identify the phonemes of a given language by decomposing them into their constituent phonological characters, that is, we establish for each phoneme the qualities it opposes to the other phonemes of the system in question.) [2]. Published in 1939 in the Proceedings of the Congress, this article is frequently regarded as the debut of the second epoch of his phonological theory, since the previously marginal issue of "sub-phonemic entities" started to be paid serious attention.

However, among the other members of the Prague Linguistic Circle throughout the 1930s, the idea about the sub-phonemic entities must have been more prevalent and established than usually believed. According to Josef Vachek (1909-1996), the insider who later wrote a history of the Circle, "the fact that the phoneme is divisible into simultaneous elements (whether one calls them phonological units or relevant phonic qualities or distinctive features) was accepted unanimously in the Prague group of the mid-thirty" [3]. Evidently, this topic was not outside the mainstream concerns of the circle in its classic period. Jakobson's Ghent article was not an abrupt break from the Praguian phonology. Therefore, to investigate how the ideas on distinctive feature was initiated, debated, and accepted in the Circle is an important step to understand the phonological theories of the Prague School in its classical period. Such investigation is possible by reconstructing a more panoramic history with the multilingual texts written by the members of the circle, especially Jakobson, Trubetzkoy and Vachek. 


\section{CONCURRENCE AND JAKOBSON's EARLIEST IDEA ON SUB-PHONEMIC ENTITY}

Despite its influence, the Ghent article was not Jakobson's first attempt to describe phonological opposition with distinctive features. He had already dealt with this issue in an article he wrote in Czech in 1931. Entitled " $Z$ fonologie spisovné slovenštiny” (On phonology of written Slovak), this article was published in a commemorate volume dedicated to the Czech philologist and literary historian Albert Pražák $(1880-1956)$ for the $30^{\text {th }}$ anniversary of his literary career. In this comparative study of Slovak vowels and their Czech counterparts, four terms were employed to classify these vowels. He grouped Czech phonemes /e/ and /i/ as "samohlásky světlo-měkké" (bright and soft vowels) and /o/ and /u/ as "samohláskám temno-tvrdým” (dark and hard vowels); on the other hand, he only labeled the opposition between Slovak /æ/, /e/, /i/ and /a/, /o/, /u/ as "samohlásky měkké” (soft vowels) vs. "samohláskám tvrdým” (hard vowels), because Slovak /æ/ and /a/ were both interpreted by him as "světlý" (bright) [4]. These four terms, "měkké", "tvrdý", "světlý", “temný”, become Jakobson's earliest attempt at the sub-phonemic entities and can be regarded as the precursors of the more standard Jakobsonian terms "acute", "grave", "non-flat", "flat". In this 1931 article, the above-mentioned four entities were also collectively denominated by Jakobson as "diferenciační vlastností" (distinctive features), which was also the earliest appearance of this term in Jakobsonian phonology, although the term is in Czech rather than in English.

Jakobson's another work in the early 1930s also mentioned the possibility to divide the phoneme into smaller constituents. In his contribution to the Czech encyclopedia Ottuiv slovnik naučný nové doby (Otto's Encyclopedia of the New Era), he termed phoneme as "soubor zvukových vlastností, kterými se liší jedna hláska daného jazyka od ostat” (set of sound features, that distinguishes in a language one sound from the others) [5]. While most of the details in this definition are consistent with "unité phonologique non susceptible d'être dissociée en unités phonologiques plus petites et plus simples" (phonological unit not susceptible of being broken into smaller and simpler phonological units) in Prague Linguistic Circle's Projet de terminologie phonologique standardisée (1931). However, a different detail is also unambiguous: As a "soubor zvukových vlastností", phoneme is no longer functionally unbreakable. Although the term "diferenciační vlastností" did not actually appear in this article, it was manifestly implied.

\section{The FEedBaCKS From Inside the Prague Linguistic CIRCLE}

Although phoneme was defined as the minimal phonological constituent in the Projet, members from the Prague Linguistic Circle never stopped their revision of it. At least two important articles can prove other members' agreement to Jakobson's idea of separable phoneme and the sub-phonemic entities. One is Trubetzkoy's "Essai d'une théorie des oppositions phonologiques" (1936); the other is Vachek’s “Phonemes and Phonological Units” (1936).
At the first glance, Nikolai Trubetzkoy (1890-1938) seemed to have disagreed with the idea of sub-phonemic entity. In Anleitung zu phonologischen Beschreibungen (1935), he defined phoneme as a phonological unit which cannot be broken down into any smaller phonological units [6]. But in his other works, phonemes are not so absolutely indivisible. To understand this contradiction, one should not forget the purpose of Anleitung: This pamphlet was distributed by International Phonological Association to its members. It was intended as a guide for them to transcribe the phonological system of their own languages. In other words, Anleitung is more of a practical manual than a theoretical presentation. Therefore, it is works like "Essai d'une théorie des oppositions phonologiques" that serve as more important sources for the understanding of Trubetzkoy's true ideas on sub-phonemic entities.

In the five categories of phonological oppositions, sub-phonemic entities automatically surface in the latter three categories. For example, in the third category, parallel oppositions $/ \mathrm{t}-\mathrm{d} /=/ \mathrm{p}-\mathrm{b} /=/ \mathrm{k}-\mathrm{g} /=/ \mathrm{s}-\mathrm{z} /=/ \mathrm{f}-\mathrm{z} /=/ \mathrm{f}-\mathrm{v} /$ are termed as "opposition proportionnelle" as opposed to unique opposition like $/ \mathrm{r}-\mathrm{l} /$. He noted that the same relationship between the two opposites repeat in the phonological system because of the "traits différentiels" possessed by each opposite (i.e. phoneme). Thus, phonemes become "une somme de qualités phonologiques” which exactly echoes Jakobson’s "soubor zvukových vlastností".

In his explanation of the difference between "opposition phonologique supprimable" and "opposition phonologique constante", sub-phonemic entities show its existence more clearly in "opposition phonologique supprimable", or in English, "neutralizable opposition”. Trubetzkoy summarized the two phonemes in an "opposition phonologique supprimable" as "archiphonème + qualité spécifique”. This interpretation anticipated its more mature version in Grundzüge der Phonologie: The unmarked form in such opposition is "Archiphonem + Null", whereas the marked form is “Archiphonem + ein bestimmtes Merkmal”. The mark is obviously a sub-phonemic entity.

In his category that included "opposition privative", “opposition graduelle”, and "opposition équipollente”, sub-phonemic entities are revealed most clearly. For example, the nasalized feature reassures the identity of nasalized vowels as opposed to their oral counterparts; the "caractère sifflant" of /s/ and the "caractère chuintant" of $/ \delta /$ guaranteed the opposition between the two fricatives.

In summary, even if Trubetzkoy's direct purpose is not to divide the phoneme into even smaller phonological units, sub-phonemic entities still turned up in his analysis.

A similar situation is also found in Vachek's interpretation of "phonological unit". In his opinion, the opposition of /b/ and $/ \mathrm{p} /$ is not the ultimate reason for the contrast between "bad" and "pad". Instead, it can be further analyzed into the opposition between what he called "sonority : 0" [7]. Therefore, all the marked form in a phonological opposition can be interpreted as "archiphoneme + mark". The real minimal phonological units are this kind of marks instead of 
the phonemes. He also noted an important characteristic of his newly discovered minimal phonological unit: Sub-phonemic units are simultaneous instead of successive [7].

\section{Successivity AND Simultaneity of Phonological UNIT IN GRUNDZÜGE}

Unlike Jakobson's phonological theory based on distinctive features, Trubetzkoy's phonological theory is generally known as based on phonemes. However, Grundzüge does not lack the implications of sub-phonemic entities. Phoneme is defined in Grundzüge as "die Gesamtheit der phonologisch relevanten Eigenschaften eines Lautgebildes" (the sum of the phonologically relevant properties of a sound) [8], which indicates that phoneme has a complex structure rather than a simple and indivisible one.

Baltaxe, the translator of the English version of Grundzüge, also warned readers of the oversimplification of Trubetzkoy's definitions of sound and phoneme. Translating his term "Lautgebilde" as "sound" is only because there is no appropriate counterpart for it in English. "Sound" is more of an equivalent for German "Laut", which lacks the connotation of an abstract and complicated structure suggested by "Lautgebilde". Trubetzkoy certainly knew Jakobson's breakthrough as he wrote Grundzüge. He reminded readers that Jakobson had made a similar definition for phoneme in the Czech encyclopedia [8].

Whenever Trubetzkoy emphasized on the minimal nature of phoneme, he always referred to phoneme as the successive distinctive phonological unit. Here, the keyword "successive" (in German "aufeinanderfolgende") must be put to the foreground. As long as the phoneme is discussed within the linear framework, it is the minimal phonological unit. On the other hand, once this condition is lifted, the reason why one sound is different from another sound no longer relies on the whole of a phoneme, but on a part of it. In other words, phonemes are contrasted by what Trubetzkoy called "phonologisch relevanten Eigenschaften" (phonologically relevant properties), and all the "phonologisch irrelevanten Eigenschaften" (phonologically irrelevant properties) can be neglected in this kind of analysis.

As for why Trubetzkoy failed to let sub-phonemic entities play an even more important role, a personal account by Jakobson may partly disclose the forgotten fact:

There was probably never in my life such a feverish profusion of new thoughts and starts as in the beginning of 1938, when I succeeded, as I thought then and continue to think, in fully carrying out the decomposition of consonantal phonemes into their fundamental oppositions.... Trubetzkoy accepted some of my ideas but stubbornly questioned the others, in particular tonality features of consonants. He felt that he was too far advanced in his book to reopen fundamental questions, particularly with regard to the classification of interphonemic relations that he adopted. So he suggested that I publish my reply on the subject after the publication of his book [9].
Jakobson's reply was put forward and then published as the Ghent article - "Observations sur le classement phonologique des consonnes", which aimed at breaking down the phoneme into "a restricted number of differential elements." Jakobson believed that such attempts were both necessary and possible because "the formulation and elaboration of phonological questions had entered a new stage" [9]. Clearly but sadly, had it not been for the political disaster of the 1938, one could well have expected to read some even more profound reflects, discussions and debates of the two great minds in the following years. But Trubetzkoy's grievous death in June tragically ended the golden days of their communication, leaving Jakobson to rue the calamities before the classical period of the Prague Linguistic Circle came to an end and he himself had to flee from persecutions. The following retrospect seems much personal but never a digression in our discussion:

It was in this work that I most acutely felt the loss of Trubetzkoy. The long period of our collaboration, which, as noted, was of the nature of a continuing dialogue and discussion, had come to an end. From now on I would have to work alone and verify for myself future findings and subsequent hypotheses. In addition it became more apparent that my vivid collaboration with the Linguistic Circle of Prague - this, as it seemed, inexhaustible center for discussion - would soon come to an end, as would later the activities of the Circle itself. For me the years of homeless wandering from one country to another had begun [9].

It is not completely surprising that Jakobson's two articles of the early 1930s did not leave a weighty influence outside the Prague Circle. The language in which they were written, together with the places where they were published, apparently hampered their availability by the broader academic world, especially in Western Europe and North America. Both of the two writings were in Czech, a language that was by no means an international academic language and few outsiders were able to read in. Moreover, " $\mathrm{Z}$ fonologie spisovné slovenštiny" (1931) was published in a volume prepared mainly for the "inner circles" of the Slavists and was hardly available to the outsiders. In addition, the entry "Fonéma” (1932) was in Ottưv slovník naučný nové doby, a popular encyclopedia that aimed at the average "lay" readers rather than the academic minds. Few Western scholars had ever read, or been able to read, the two articles until they were translated into English and included in Jakobson's Selected Writings in the mid-1960s. They were then rediscovered as something unexpectedly inspiring. But it must be emphasized that an analysis of all the above mentioned sources written in various languages has indicated that the idea of sub-phonemic entities had existed well before the Ghent congress in 1938.

TABLE I: Sub-Phonemic Elements as Mentioned By the Prague PHONOLOGISTS

\begin{tabular}{||l|l|l|}
\hline \hline Linguist & Language & Term \\
\hline Jakobson & Czech & diferenciační vlastností \\
\hline Vachek & English & phonological units \\
\hline Trubetzkoy & German & phonologisch relevanten Eigenschaften \\
\hline Jakobson & French & qualités \\
\hline Jakobson & English & distinctive features \\
\hline
\end{tabular}




\section{CONCLUSION}

The idea of "distinctive feature" had already been initiated in the early 1930s and became mature in the mid and late 1930s along with the deeper discussions in the Circle. The idea of a breakable phoneme was mentioned by several members of the Circle, although the terms that they employed did not necessarily overlap (See Table I).

Although Jakobson did not clearly emphasize the non-linear (or, paradigmatic) nature of the distinctive features, such nature gradually surfaced in the discussion within the Circle. The non-linear nature of sub-phonemic entities was thus finally accepted and established and became an important revision to the limitation of Saussure's view on linguistic sign. However, since the source texts that witnessed this history were written in various languages, some of which in non-international language, they are sometimes unfairly neglected. But obviously, these texts are valuable for the research on the history of linguistics.

\section{REFERENCES}

[1] S. Anderson, Phonology in the Twentieth Century, Chicago: The University of Chicago Press, 1985, ch. 5, pp. 116-139.

[2] R. Jakobson, "Observations sur le classement phonologique des consonnes," in Selected Writings, vol. 1, R. Jakobson, Ed. The Hague: Mouton, 1939/1971, pp. 272-279.

[3] J. Vachek, The Linguistic School of Prague, Bloomington: Indiana University Press, 1966, ch. 3, pp. 40-78.

[4] R. Jakobson, "Z fonologie spisovné slovenštiny," in Slovenská Miscellanea, J. Jirásek and F. Tichý, Eds., Bratislava: Universum, 1931, pp.155-163.

[5] R. Jakobson, "Fonéma," in Ottův Slovník Naučný Nové Doby, vol. 2, no. 1, K. Mádl, Ed., Praha: J. Otto, 1932, p. 608.

[6] N. Trubetzkoy, Anleitung zu Phonologischen Beschreibungen, Göttingen: Vandenhoeck \& Ruprecht, 1935/1968, ch. 1 (A), pp. 9-13.
[7] J. Vachek, "Phonemes and phonological units," in Travaux du Cercle Linguistique de Prague 6: Études dEdiées au Quatrième Congrès de Linguistes, Prague: CLP, 1936, pp. 235-239.

[8] N. Trubetzkoy, Grundzüge der Phonologie, Prague: Jednota Československých Matematiků a Fysiků, 1939, ch. 1, pp. 30-41.

[9] R. Jakobson and K. Pomorska, Dialogues, Cambridge: Cambridge University Press, ch. 4, pp. 27-24.

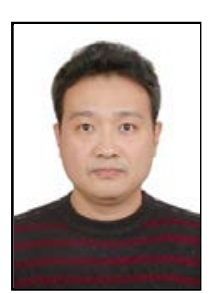

Changliang Qu was born in Dalian, China on April 1, 1980. He earned his Ph.D in linguistics in 2011 at the Department of English language and literature, School of Foreign Languages, Peking University, Beijing, China. His major fields of study are linguistic historiography, phonology, and history of English.

With the fund from China Scholarship Council, he spent the 2009-2010 academic year as a visiting scholar at the Department of Linguistics, School of Literatures, Cultures and Linguistics, University of Illinois at Urbana-Champaign, U.S.A. He is currently an associate professor of linguistics at Dalian University of Foreign Languages, Dalian, China. His main publication includes A Study of Jakobsonian Phonology: Opposition, Distinctive Features and Sound Shape , Beijing: World Publishing Corporation, 2015, his Chinese translation of Stephen Anderson's Phonology in the Twentieth Century, Beijing: The Commercial Press, 2015, and the Chinese introductions he wrote for the English reprints of A Modern English Grammar on Historical Principles, vol. 1, Beijing: World Publishing Corporation, 2014, and Selected Writings of Otto Jespersen, Beijing: World Publishing Corporation, 2016. His research interests are linguistic historiography, phonology, lexicography, language change and language varieties, Chinese languages and dialects, Western humanities.

Prof. Qu is a member of Asian Association for Lexicography (ASIALEX). $\mathrm{He}$ is also a contributor to the publishing project "Reprinting Classics in Western Linguistics” organized by Beijing World Publishing Corporation. 